\title{
Evaluation of Seed Test Weight on Major Field Crops
}

\author{
${ }^{* 1}$ Deivasigamani $\mathbf{S},{ }^{2}$ Swaminathan $\mathbf{C}$ \\ *I Division of Soil and Crops, Krishna College of Agriculture and Technology (KRISAT), \\ (Affiliated to Tamil Nadu Agricultural University), Srirengapuram, Madurai district, Tamil Nadu, India. \\ *Corresponding Author: Deivasigamani S, Division of Soil and Crops, Krishna College of Agriculture \\ and Technology (KRISAT), (Affiliated to Tamil Nadu Agricultural University) Srirengapuram, Madurai \\ district, Tamil Nadu, India.
}

\begin{abstract}
The research work was accomplished at the laboratories of the field crops in, Krishna College of Agriculture and Technology (KRISAT), Srirengapuram, Usilampatty, Madurai, Tamil Nadu, India during 2017. To study the evaluation of test weight on different categories of field crops like, cereals, millets, small millets, pulses, oilseeds, fiber, narcotics, fodder and green manure crops were counted and computed the data's in this article. The number of seeds was taken in to by hand count on 100 and 1000 seed weight was measured in weighing balance $(\mathrm{g} / \mathrm{mg})$. There are five different samples were collected in each and every crop seeds and average values are computed. The values have been used for estimation/working out of seed rate for raising the crops in unit of land. A lower test weight equals to lower value and higher test weights generally fetch the best price and provide the best quality of grains. Test weight is the weight of seeds per unit volume and is expressed in $\mathrm{kg}$ per ha.
\end{abstract}

Keywords: Field crops seed, cereals, millets, pulses, oilseeds, fiber, narcotics, fodder and green manure, test weight $(g)$,

\section{INTRODUCTION}

Test weight is an important predictor for milling of yield; test weights are measured on grain loads by weighing a known volume of grain, which is used to compare grain densities. If lower test weights than the accepted standard are recorded than more grain volume is needed for storage or transportation. If high test weights are recorded than less grain volume is needed. Low test weights tend to result from poor grain fill and environmental conditions in the field before harvest. The 1000 grain weight is a very important measure of seed quality, which is effective on sprouting, seed potential, seedling growth, and plant performance (Hossein Afshari et al., 2011). This quality is dependent on the size of embryo and reserved nutrients quantity used for sprouting and growth (Ebadi and Hisoriev, 2011; Cao et al., 2011).

Test weight is used as an indicator of general grain quality and is a measure of grain bulk density. Test weight, but not overall grain weight, normally increases during drying. Use of test weight in grain industry it can be used to determine the grain values (Carl Bern and Thomas, 2009). The test weight of a representative sample of your crop will give an indication of how it compares to the industry standard. A lower test weight equals lower value or higher test weights generally bring the best price and provide the best quality when fed to livestock. There is a popular belief that if a specific corn hybrid has high test weight that it will also be high yielding. When it fact, that there is very little correlation between high test weight and high yields (Nielsen, 2014).

Test weight is simply a measure of grain bulk density. An official test weight measurement uses standardized equipment to determine the mass (weight) of a sample quart of grain, and then converts this to a $\mathrm{g} / \mathrm{mg}$. Grain is prevented from filling completely and/or maturing and drying naturally in the field due to a killing frost, hail, or insect damage. When this happens the starch molecules inside the grain are prevented from the natural process of shedding absorbed water molecules that allows the grain to shrink to a normal size. Artificial drying with heat removes this excess water but the starch molecules do not shrink and grain size doesn't change appreciably, so test weight or density remains low. Although the grain may again dry in the field, the seed size does not change and the small voids inside the seed result in a decreased test weight. Maximum test weight is achieved when grain is 
harvested on the first dried and also at higher ideal harvest moisture for soybeans and corn is 16-19\% moisture and 20-25\% moisture respectively. (Robert Kratochvil, 2016).

The estimation or working out of seed rate for raising the crops in unit of land. A lower test weight equals lower value. Standard or higher test weights generally bring the best price and provide the best quality when fed to livestock on farm. The yield of a crop depends on establishment of a crop, choice of seed; optimum population, plant geometry, time and method of sowing are the factors that influence the crop establishment and yield. Plant population refers to the number of plants per unit area.

\section{Materials ANd Methods}

The research work was carried out at the Laboratories of the field crops in Krishna College of Agriculture and Technology (KRISAT), Srirengapuram, Usilampatty, Madurai, Tamil Nadu, India during 2017. To study the evaluation of test weight on different categories of field crop seeds like, cereals, millets, small millets, pulses, oilseeds, fiber, fodder and green manure crops were counted and computed. The number of seeds were taken in to by hand count on 100 and 1000 seed weight was measured in $(\mathrm{g} / \mathrm{mg})$ and used to estimate the seed rate based on fixed number of seeds and test weight. There are five different samples were collected in each and every crop seeds and average values are computed in the table $(1 \& 2)$. The values have been used for estimation/working out of seed rate for raising the crops per unit of land.

Seed rate $\left(\mathrm{kg} \mathrm{ha}^{-1}\right)=\frac{(1000 x \text { thousand seed weight or hundred seed weight } X 100 \mathrm{X100})}{(1000 X 1000 X \text { purity } \% \text { g germination } \% 6 \text { spacing meters })}$

Seeds test weight is the weight of seeds per unit volume and is expressed in kg per ha. Test weight in terms of weight is an important parameter as it gives an indication of seed chemical composition, seed dampness, insects infestation and seed maturation etc. The data were subjected to statistical analysis for finding standard error values.

\section{RESULTS AND DISCUSSIONS}

It is the weight in grams of 100 and 1000 seeds the seed size can vary from one crop to another, between varieties of the same crop and even from year to year or from field to field of the same variety. Because of this variation in seed size, the number of seeds and, consequently, the number of plants in a seed is also highly variable and by using the 100/1000 grain weight, a producer can account for seed size variations when calculating seeding rates, calibrating seed drills and estimating shattering and combine losses. Conley and John (2013) stated that test weight is an important factor to consider when selecting a variety as both environment and pests may greatly affect test weight therefore, selecting a variety that has a high test weight potential in any area is critical to maximizing economic gain.

Greenaway et al. (1997) reported that breeders used test weight as a general guide to combine characteristics such as kernel plumpness (fullness), density. The quality of grains as the plantreplicating organ and the most important element in the production of agronomic crops has a very special position and effect on the nice performance and growth of agronomic crops. This is influenced by many different factors such as genetic features, nominal potential or sprouting potential, seed potential, humidity, storage quality, seed preservation and health, but the most important ones are sprouting rates and seed potential by (Malcolmet et al., 2003; Akbari et al., 2004). Test the 1000 seed weight has significant effects on sprouting percentage and dry seeding weight, while it has no significant effect on seedling length by (Mashtati et al., 2008; Sharma et al., 2011).

Based on the above results it can be concluded that the grain test weight was an indicator of generally grain quality and test weight were evaluated. In normally increases grain test weight was dried in proper manner and lower test weight equals to lower value and higher test weights improve the best price and provide the best quality also. In sequence of 1000 and 100 seed weight has significant effects on test weight in most of the field crops like, cereals, major millets, minor millets, pulses, oilseeds, fiber, green manure and fodder etc., but it has no significant effect on germination. The values have been used for estimation/working out of seed rate for raising the crops per unit of land. 
Table1. Evaluation of 1000 seed Test weight on different field crops

\begin{tabular}{|c|l|c|c|}
\hline S.no & \multicolumn{1}{|c|}{ Name of the crop } & Mean Test weight (g) & Standard Error (S.E) \\
\hline & Cereals & & \\
\hline 1 & Paddy & 19.18 & 0.57 \\
\hline 2 & Wheat & 46.18 & 0.36 \\
\hline & Major millets & 31.01 & 0.49 \\
\hline 3 & Sorghum & 12.25 & 0.37 \\
\hline 4 & Cumbu & 3.23 & 0.24 \\
\hline 5 & Ragi & & 0.26 \\
\hline & Small millets & 3.76 & 0.23 \\
\hline 6 & Barnyard millet & 3.35 & 0.25 \\
\hline 7 & Foxtail millet/Thenai & 3.17 & 0.33 \\
\hline 8 & Little millet/Samai & 6.74 & 0.35 \\
\hline 9 & Kodomillet/ varagu & 6.30 & \\
\hline 10 & Panivaragu & & 0.31 \\
\hline & Oilseeds & 4.33 & \\
\hline 11 & Gingelly & & 0.047 \\
\hline & Narcotics & 0.91 & \\
\hline 12 & Tobacco & & \\
\hline
\end{tabular}

Table2. Evaluation of 100 seed weight on different field crops

\begin{tabular}{|c|c|c|c|}
\hline S.no & Name of the crop & 100 seed weight $(g)$ & Standard Error (S.E) \\
\hline & Cereals & & \\
\hline 1 & Maize & 29.82 & 0.44 \\
\hline \multirow[t]{2}{*}{2} & Barley & 3.24 & 0.30 \\
\hline & Pulses & & \\
\hline 3 & Red gram & 11.57 & 0.35 \\
\hline 4 & Black gram & 6.62 & 0.24 \\
\hline 5 & Green gram & 7.38 & 0.27 \\
\hline 6 & Cowpea & 20.31 & 0.30 \\
\hline 7 & Cowpea -White & 19.81 & 0.25 \\
\hline 8 & Soybean-pale yellow & 15.69 & 0.29 \\
\hline 9 & Soybean-white & 15.73 & 0.28 \\
\hline 10 & Soybean-black & 19.25 & 0.36 \\
\hline 11 & Rajmaa & 46.28 & 0.33 \\
\hline 12 & Horse gram & 4.43 & 0.326 \\
\hline 13 & Horse gram-black & 3.84 & 0.26 \\
\hline 14 & Garden lablab & 28.66 & 0.31 \\
\hline 15 & Garden lablab-black/purple & 30.28 & 0.33 \\
\hline \multirow[t]{2}{*}{16} & Peas -green & 24.89 & 0.45 \\
\hline & Oilseeds & & \\
\hline 17 & Groundnut & 36.97 & 0.41 \\
\hline 18 & Sunflower & 5.97 & 0.40 \\
\hline 19 & Castor & 41.68 & 0.25 \\
\hline \multirow[t]{2}{*}{20} & Mustard-big & 3.23 & 0.30 \\
\hline & Fiber & & \\
\hline 21 & Cotton with fuzz & 11.70 & 0.32 \\
\hline 22 & Cotton without fuzz & 10.45 & 0.36 \\
\hline \multirow[t]{2}{*}{23} & Mesta & 3.30 & 0.28 \\
\hline & Fodder crop & & \\
\hline 24 & Fodder maize & 36.98 & 0.40 \\
\hline 25 & Fodder sorghum & 22.56 & 0.48 \\
\hline 26 & Lucerne & 2.73 & 0.33 \\
\hline \multirow[t]{2}{*}{27} & Agathi & 7.98 & 0.40 \\
\hline & Green manure & & \\
\hline 28 & Kolinji & 2.56 & 0.30 \\
\hline 29 & Daincha & 2.72 & 0.31 \\
\hline 30 & Sunhemp & 3.52 & 0.24 \\
\hline
\end{tabular}




\section{REFERENCES}

[1]. Ebadi AG, Hisoriev H, (2011). Review on Distribution of Sambucus ebulus L. In the North of Iran. Am. Euras. J. Agric. Environ. Sci., 10(3): 351-353.

[2]. Cao HW, Zhang H, Chen ZB, Wu ZJ, Cui YD, (2011). Chinese traditional medicine matrine: A review of its antitumor activities. J. Med. Plants Res., 5(10): 1806-1811

[3]. Hossein Afshari, Mostafa Eftekhari, Miad Faraji, Abdol Ghaffar Ebadi and Abbas Ghanbarimalidareh, (2011). Studying the effect of 1000 grain weight on the sprouting of different species of Salvia L. grown in Iran Journal of Medicinal Plants Research Vol. 5(16), pp. 3 991-3993, 18 August,

[4]. Nielsen R.L, 2014.Test Weight Issues in Corn, Agronomy Dept., Purdue University; in 47907-2054

[5]. Conley S, John G (2013). Top 7 Recommendations for Winter Wheat Establishment, University of Wisconsin agronomy, soybean research, University of Wisconsin-Extension. www.coolbean.info.

[6]. Greenaway WT, Watson CA, Davis G, (1997). Factors for converting bushel weight to hectoliter weight for six cereals grains, flax, and soybeans. Cereal Chem. 54(2):373-378

[7]. Carl Bern and Thomas J Brumm, (2009). Iowa state uiversity extenstion. U.S. Department of Agriculture. Iowa State University of Science and Technology, Ames, Iowa.

[8]. Robert Kratochvil, (2016). Wheat test weight. Extension Agronomist, University of deiaware

[9]. Akbari GE, Ghassemi Pirbalouti EA, Najafabadi M, Shahverdi M, (2004). Studying the Effects of Different Harvest Times of Soy Beans on its Sprouting. Agric. J., 1(6): 9-18.

[10]. Malcolm et PJ, Holford P, Mc Glasson W B, Newman S, (2003). Temperature and seed weight affect the germination of Peach rootstock seeds and the growth of root stock seedlings. Sci. Hortic., 98: 247-256.

[11]. George MHA, Ray DT, (2004). Germination Characterization of Guayule Seed and Morphology Mass and X-Ray and Analysis. Ind.Crops Prod., 23: 59-63.

[12]. Mashtati E, Hejazi A, Kianmehr MH, Sadat Noori SA, Gharineh MH, Mousavi SH, (2008). Effects of 1000 Seed Weight on Sprouting and Seed Potential of Wheat, Summary of Articles Presented to the First National Iranian Congress of Seed Science and Technology, Goran.

[13]. Sharma H, Parihar L, Parihar P, (2011). Review on cancer and anticancerous properties of some medicinal plants. J. Med. Plants Res., 5(10): 1818-1835.

Citation: S. Deivasigamani, C. Swaminathan, " Evaluation of Seed Test Weight on Major Field Crops", International Journal of Research Studies in Agricultural Sciences, vol. 4, no. 1, p. 08-11, 2018. http://dx.doi.org/10.20431/2454-6224.0401002

Copyright: () 2018 Authors. This is an open-access article distributed under the terms of the Creative Commons Attribution License, which permits unrestricted use, distribution, and reproduction in any medium, provided the original author and source are credited. 